\title{
Reviewing Identity Politics from Pancasila Democracy
}

\author{
Agus Supratikno \\ \{agus.supratikno@uksw.edu\} \\ Satya Wacana Christian University, Indonesia
}

\begin{abstract}
In the Reformation era, identity politics rose in Indonesia, resulting in ethnic and religious conflicts, religious fundamentalism and radicalism with an agenda to enforce Islamic Sharia, and a political maneuver in political contestation. This article discusses identity politics from Pancasila Democracy. This study uses a qualitative literature study method with a content analysis approach. This approach includes all analysis of the content of the text to conclude efforts to find the characteristics of the text objectively and systematically. The study results that the clash of ethnic, religious, and ideological-based identity politics has occurred since the beginning of the Independence of Indonesia. The feud arose because each group wanted to fight for its primordial identity politics to fill Indonesia, mainly nationalist and religious groups. The feud could be reconciled by making Pancasila the ideology of the Indonesian nation. Pancasila is the result of the agreement of the nation's founding fathers to glue together the diversity of ethnicities, religions, and ideologies that live in Indonesia.
\end{abstract}

Keywords: Identity Politics; Pancasila Democracy; Indonesian National Identity; Founding Fathers

\section{Introduction}

Some scholars warn that ethnic identity-oriented political activity is the cause of serious conflict in modern society. The world is experiencing a politic of identity renaissance that threatens to destroy established democratic systems. (Leach, Brown, and Worden 2008:760). Larry Diamond (2015: 141142) described the post-crisis year as a "democratic recession," with the total number of democracies dropping from peaks in almost every region of the world. After three decades, it developed significantly until the early 2000s. The most speeding up occurred in 1989-91 when the communism in Eastern Europe and the former Soviet Union fell and unleashed a wave of democracy throughout the region. However, since the mid-2000s, the direction has been opposite, and the whole number has decreased.

Nuanced religious conflicts mark the rise of identity politics in Indonesia's modern politics in several areas, the emergence of religious fundamentalism and radicalism with an agenda to enforce Islamic Sharia in the state as well as the use of ethnic and religion as a means of gaining victory in the contestation of power politics in 2017 Jakarta Gubernatorial Election, and Presidential election in 2019 (Susilowati et al. 2019:322). According to Fukuyama (2018a), identity-based politics in the modern democratic landscape is one of the threats in democratic life. Therefore, it is necessary to develop a universal perspective on human dignity. Furthermore, to maintain a secure political order, it is necessary to reaffirm an inclusive national identity. A strong national identity is needed to improve security, build good governance, improve the economy, foster mutual trust among citizens, improve social safety nets, and ultimately safeguard the development of liberal democracy. (Fukuyama 


\section{Result and Discussion}

\subsection{The Identity Politics}

Identity politics aims to gain sectoral superiority by deliberately targeting groups that share common essential characteristics such as race, gender, sexual orientation, religion, and ethnicity. It is a term that refers to intervention (Young 2019: 3).

Fukuyama states that over the several latter decades, the central axis of politics has shifted from a focus on economic issues to a focus on identity politics and from distribution issues to cognitive issues. Globalization has risen an exclusive nationalism that threatens the landscape of liberal democracy worldwide. Nationalism and religion will always exist as political forces in the modern political landscape of the world. Although liberal democracy normatively guarantees all citizens' equality, it does not warrant that citizens are respected equally in democracy, particularly in a group that has experienced being marginalized (Fukuyama, 2018a).

As a result, isothymia will continue to press for equal recognition, likely falling short. The struggle for equal recognition by groups who have been disenfranchised in society drives contemporary identity politics. That desire, however, can swiftly morph into a demand to acknowledge the group's superiority (megalothymia). It is a huge component of today's nationalist and national identity stories and some forms of fanatical religious politics. (Fukuyama 2018:29)

In Indonesia's modern politics, identity politics is developed from several groups part of the majority group, who want to eliminate minority groups. According to Mulia in Maarif (2010:44), identity politics in Indonesia emerged from the majority religious groups who wanted to eliminate minority groups considered deviant. The currents of Muslim identity politics, especially those carried out by Islamic fundamentalist groups, have resulted in physical and symbolic violence: (1) physical violence: closing churches and mosques. Other physical violence causes the object of violence to be traumatized, injured, and died; (2) symbolic violence in writings or lectures that insult other religions.

To address identity politics in the modern US political landscape, Fukuyama proposes to focus on economic policies and distributional politics and strengthen their commitment to the national creed. The creed must be a belief that most citizens agree on and assimilate immigrants. Meanwhile, Mutua argues that such creeds are, on the one hand, inspirational and perhaps aspirational, but on the other hand, it is often misused by elite groups to cover up domination and the privileges of the white race. (Mutua 2020:5)

\subsection{Democracy of Pancasila}

Pancasila democracy is a concept of democracy that stems from the Indonesian nation's personality and philosophy of life. It is based on the following principles: democracy led by wisdom in deliberations/representatives, insight from Godhead, humanity that is fair and civilized, and a united Indonesia to achieve social justice for all Indonesians (Wisnumurti 2017). In the heterogeneous Indonesian context of multiple ethnic, racial, religious, and intergroup tensions, the nation's founders' choice of Democrazy of Pancasila is a wise move. According to Article 1 paragraph (2) of the 1945 Constitution of the Indonesian State, Pancasila democracy is a constitutional democracy which unique. The uniqueness of Pancasila democracy is in its spirit, which is the religious, humanist, collectivism-kinship. Using the 
institutions of modern democracy but in decision-making, use the mechanism of indigenous culture deliberation.

\subsection{The Dynamics of Identity Politics in Indonesia}

After Indonesia became independent and colonialism was no longer considered a common enemy, primordialism based on ethnicity, religion, and ideology emerged to identity politics. Three major ideologies developed at that time that was scrambling to fill the national identity, namely Nationalist, Islamic and Marxist. Nationalism comes from traditional Javanese culture, which is strong, rich, and majority, representing national identity. This situation was also supported by a group that identified itself as part of the Budi Utomo movement, a traditional movement of educated Javanese in the early 20th century in the Dutch East Indies (before becoming Indonesia). Second, Islamic ideology is supported by some Islamic movements, which believe that because most of Indonesia's population is Muslim, Islam should be logically become a national identity. While the third, Marxism, as the face of socialism, is supported by groups with Western educational backgrounds, who believe that the modern state should be based on equality, justice, and democratic principles (Titaley 2013:158-59).

The contradiction that most colored the struggle over the form of the state at the beginning of Indonesia's Independence was between the Nationalist group and the Islamic group. The two groups are fighting for influence to become the state's ideology. This polemic is perfectly visible in the debates in the sessions of the BPUPKI ( Investigating Committee for Preparatory Work for Indonesian Independence). The polemic resulted in the agreement of the Jakarta Charter with the contents as seen today. Namely, by eliminating the seven words in the first precepts relating to the obligation for Muslims to carry out Islamic law (Ma'arif 2017:193). The history of the development of Pancasila and its changes from Soekarno's Pancasila, to the Jakarta Charter of Pancasila, to Pancasila on August 18, 1945, which gave birth to Indonesian religiosity, had a significant impact on this nation (Titaley 2013:160). Pancasila, which was decided on August 18, 1945, placed all religions, ethnicities, and followers equally. The Pancasila, established on August 18, 1945, places all religions, ethnicities, and groups adherents equally. The fifth precept of Pancasila expressly guarantees the equal rights of every citizen. Every citizen has the same rights and obligations before the law, even in the world of politics. Thus, in principle, Pancasila does not recognize the relationship between the majority and the minority. Also, Pancasila does not affirm the dictatorship of the majority and the tyranny of the minority. The commitment to abolish the seven words must be understood as an attempt to put all residents equally. Such equality includes equal rights, freedoms, and opportunities by which they are enabled to initiate dialogue on fundamental issues (Ma'arif 2017)

The founding father had big dreams about the future of Indonesia, namely, so that the Indonesian state would not fall into one particular group or political power (left or right). Instead, it belongs to all Indonesian people with diverse ethnicities, religions, and ideologies. The agreement of the founding fathers of this nation is a foundation for a new, plural country, namely Indonesia, which is based on Pancasila, and this is Indonesia's national identity. Even though there has been an agreement on the state ideology based on Pancasila on August 18, 1945 , it does not mean that there was no political upheaval after the Indonesian Independence. History records various identity political turmoils, and even separatism has occurred in several parts of Indonesia. Maarif briefly describes, as follows: RMS (Republic of South Maluku), GAM (Free Aceh Movement), and GPM (Free Papua Movement), DI (Darul Islam) use 
religion as their identity politics, the PKI (Indonesian Communist Party) in Madiun, 1948, the PRRI/Permesta rebellion in the late 1950s to early 1960s in Sumatra and Sulawesi. The PKI used Marxism as its identity politics, while the PRRI/Permesta was more of a protest movement against Sukarno's politics. Furthermore, the last one was the events of G30S 1965.

President Soeharto turned off identity politics during the New Order by declaring Pancasila the sole principle of all social and political institutions. He creates a myth by instilling a sense of national identity with stable features. Strong nationalism, a focus on consensus, authority respect, rejection of communism, Islamism, or Western liberalism, and the apotheosis of national ideology and the 1945 Constitution is among these ideals. The constitution is unchangeable. Suharto established tight social and political controls by monopolizing the definition of national identity, charging those with alternative opinions of being subversive and enemies of the state. (Yuwanto, 2013)

After the Suharto regime fell in 1998, identity politics resurfaced in Indonesia: movements for fundamentalism and religious radicalism thrived. Some of them are the Indonesian Mujahedeen Council, the front for defenders of Islam, and Hizb ut-Tahrir. This movement is often anti-democracy, pluralism, and nationalism. Meanwhile, the same movement but through a constitutional route is establishing the Prosperous Justice Party, an Islamic party influenced by al-Ikhwan al-Muslimun founded by Hasan Al-Bana in Egypt, following the democratic path to achieve its goals. Applying Islamic Shari'ah in the state is a demand shared by all of these factions (Maarif 2010:21). They do not recognize the Unitary State of the Republic of Indonesia as a legitimate and final state, and they strive to replace Pancasila's ideology and the Unitary State of the Republic of Indonesia (Dahlan 2014:19). In the 2017 Jakarta Gubernatorial Elections, identity politics was also used, with one candidate frequently using religious issues to mobilize voters. The use of ethnic and religious identity politics was crucial in Anies-victory. Sandi's During the 2017 Jakarta election, the rise of religious sentiment successfully divided Indonesia into nationalist and religious groups (Arjon 2018:172). In the 2017 DKI elections, identity politics and political representation orientation influence the democratic process. (Nasrudin 2019:1)

Politics is often concerned with the struggle for resources between different identity groups. Therefore, identity politics will always appear in political life in one form or another. Identity politics must be reconfigured to support cross-sectoral identities that promote social cohesion rather than reinforcing ethnic and religious divisions whose exclusivity fosters fragmentation and conflict (Phillips 2016:5)

\subsection{Reviewing Identity Politic From Pancasila Democracy}

The legitimacy of the nation-state is based on "the self-identification of communities of people who consider themselves to have observable sovereignty and the identification of political units that unite culturally homogeneous groups." In other words, a cohesive nationstate requires a certain degree of homogeneity among the peoples. Homogeneity is artificially created using national identities that distinguish a particular nation-state from non-members. Thus, nation-states create national identities based on what Anderson called "imagined communities" because they differ "in style imagined rather than false/authentic." (Anderson 1983:33)

The Indonesian national identity is formed not because of the similarities people have in common but by the psychological feeling of having the same fate as the colonized. During colonialism, this diversity can be united by the same psychological feelings as the colonized. According to Yuwanto (2013:5), shared experience as colonized under Dutch colonialism 
became the main factor that united the heterogeneous Indonesian society. The nationalist group succeeded in building the national identity of Indonesia that unites ethnic, race, and religious differences in the spirit of a common struggle to fight colonialism and build a new Indonesian identity. It shows that the spirit of nationalism can unite diversity for a common enemy. The spirit of nationalism erodes the existing boundaries of primordialism.

Nevertheless, after Indonesia became independent and colonialism was no longer considered a common enemy, primordialism based on ethnicity, religion, and ideology emerged that gave birth to identity politics. One and the main is an ideological conflict. Three major ideologies developed at that time that was scrambling to fill the national identity, namely Nationalist, Islamic and Marxist. These three significant ideologies are scrambling to become the nation's ideology. The most intense struggle is between religious ideology (Islam) and nationalist ideology. The feud can be reconciled with the stipulation of Pancasila as the basis for the founding of Indonesia.

According to Titaley (2013:157), forming Indonesian is something uniquely Indonesia. Sociologically, Indonesia has two identities: Primordial before Indonesia was formed. This identity has been carried over since they existed, including diversity, culture, and religions. People of Java, Aceh, Minangkabau, Timor, Maluku, and others in this identity. This variety of primordial identities creates Indonesian pluralism. And then, in their primordial identity, they create a new identity that unites them into a nation. It is the national identity called Indonesia. Before Indonesia was founded in 1945, there had never been a unit called Indonesia in history. Indonesia is a new phenomenon founded by people who have their own primordial identity.

Furthermore, the political system of Indonesia as a nation is based on Pancasila (Five Principles), which becomes the Indonesian state philosophy formulated by the Indonesian nationalist leader Sukarno. It was first articulated on June 1, 1945, in a speech delivered by Sukarno to the preparatory committee for Indonesia's Independence. Sukarno argued that the future Indonesian state should be based on Pancasila (Five Principles): (1) Indonesian nationalism; (2) internationalism, humanism; (3) consent or democracy; (4) social prosperity, ; (5) and belief in one God. Pancasila has become the basis of the Indonesian state. According to Titaley (2013:160), the Pancasila applied by Soekarno placed religious and non-religious adherents (Socialists and Marxists) in the same position. The principle of diversity is in line with the declaration of equal humanity by the Parliament of the world's religions that all human beings must be treated humanely. The four humanitarian commitments include (1) a non-violence culture, (2) a solidarity culture towards a just economic order, (3) a tolerance culture and mutual trust, (4) a culture of respecting equal rights and cooperation between men and women.

Pancasila, contained in the 1945 Constitution, has a few different words: Belief in One Supreme God, just and civilized humanity, Indonesian unity, democracy under the guidance of wise representative deliberation, and social justice for all Indonesian people (Britannica 2021). In principle, Pancasila democracy guarantees every citizen's legal and political rights with their ethnic, religious, cultural, and even ideological backgrounds.

The existence of Pancasila constitutionally as the basis of the state, as well as a philosophy and belief system, becomes social capital to develop a democracy that guarantees freedom, tolerance, and religious harmony, creating stability and social integration. The nation's history proves that the Indonesian nation still exists despite the challenges of past socio-political upheavals, centralized authoritarian rule, subversion, and global economic power (Ar 2018). Pancasila is a historical testament that defends the principle of equality. With the principles of just and civilized humanity, humanitarian commitment, and the bonds of brotherhood of the 
Indonesian people penetrate local, national, or regional boundaries, reaching out to brotherhood between people and between nations globally. (Latif 2016)

\section{Conclusion}

The reemergence of identity politics in Indonesia is marked by nuanced religious conflicts, the emergence of religious fundamentalism, and radicalism with an agenda to enforce Islamic Sharia in the state's life. It is like a repetition of history at the beginning of the formation of Indonesia, where several groups fought for their primordial political ideology to fill Indonesia. Therefore, it is crucial to refresh Titaley's sociological perspective, emphasizing that Indonesian society has two identities: Primordial identity before Indonesia's Independence. Second, the Indonesian national identity is based on Pancasila, which was formed from the diversity of primordial identities since the Independence of Indonesia. Pancasila is the "common ground" that connects the differences in ethnic, religious, and ideological backgrounds that grow in Indonesia. Therefore, the solution to overcoming identity politics in Indonesia is to reaffirm the nation's identity and a democratic political system based on Pancasila, as agreed by the founding fathers of the Indonesian nation.

\section{References}

[1] Anderson, Benedict. 1983. Imagined Communities: Reflections on the Origin and Spread of Nationalism. London: Verso.

[2] Ar, Endang Danial. 2018. "Pancasila Dan Kematangan Demokrasi Indonesia'." Majelis: Media Aspirasi Konstitusi 9:15-24.

[3] Arjon, Sugit Sanjaya. 2018. "Religious Sentiments In Local Politics." Jurnal Politik 3(2):171.

[4] Britannica, The Editors of Encyclopaedia. 2021. "Pancasila." (October 2013):1-2. Retrieved (https://www.britannica.com/topic/Pancasila).

[5] Dahlan, Moh. 2014. "Hubungan Agama Dan Negara." Analisis: Jurnal Studi Keislaman 14(1):1-28.

[6] Diamond, Larry. 2015. "Facing Up to the Democratic Recession Larry Diamond." Journal of Democracy 26(1):141-55.

[7] Fukuyama, Francis. 2018a. Identity: The Demand for Dignity and The Politics of Resentment. New York: Farrar, Straus, and Giroux.

[8] Fukuyama, Francis. 2018b. "Why National Identity Matters." Journal of Democracy 29(4):5-15. DOI: 10.1353/jod.2018.0058.

[9] Heyes, Cressida. 2020. "Identity Politics." The Stanford Encyclopedia of Philosophy.

[10] Leach, Colin Wayne, Lisa M. Brown, and Ross E. Worden. 2008. "The Role of Ethnic Identity and Politics in Conflict." Ethnicity And Identity Politics 758-68.

[11] Ma'arif, Samsul. 2017. "Relasi Agama Dan Politik Menurut Rawl (Telaah Tentang Pancasila Sebagai Public Reason ).” Jurnal Filsafat 189-201.

[12] Maarif, Ahmad Syafii. 2010. Politik Identitas Dan Masa Depan Pluralisme Kita. Jakarta: Pusat Studi Agama dan Demokrasi.

[13] Mutua, Athena. 2020. "Liberalism's Identity Politics: A Response to Professor Fukuyama." University of Pennsylvania Journal of Law and Social Change 23(1):27. 
[14] Nasrudin, Juhanah. 2018. "Politik Identitas Dan Representasi Politik." Jurnal Studi Agama-Agama 1(1):34-47.

[15] Phillips, Ann L. 2016. "The Impact of Identity Politics on the Monopoly on the Use of Force." The Friedrich-Ebert-Stiftung (FES) 1-5.

[16] Susilowati, Ida, Zahrotunnimah, and Nur Rohim Yunus. 2019. "Identity Politics' Issue In Indonesia Presidential Election 2019." Journal of Legal Research 1(2):322-35.

[17] Titaley, John. 2013. Religiositas Di Alinea Tiga: Pluralisme, Nasionalisme Dan Transformasi Agama-Agama. Salatiga: Satya Wacana University Press.

[18] Wisnumurti, Anak Agun G. Oka. 2017. Democracy of Pancasila: The Concept and Its Implementation in Indonesia. Queensland.

[19] Younge, Gary. 2019. "The Politics of Identity: From Potential to Pitfalls, and Symbols to Substance." Identities 26(1):1-11. doi: 10.1080/1070289X.2018.1508859.

[20] Yuwanto. 2013. "Politics of National Identity: Comparative Analysis on Indonesia and South Korea." Politika: Jurnal Ilmu Politik 3(1):117-22.

[21] Fukuyama, Francis. 2018. Identity: The Demand for Dignity and The Politics of Resentment. New York: Farrar, Straus, and Giroux.

[22] Titaley, John. 2013. Religiositas Di Alinea Tiga: Pluralisme, Nasionalisme dan Transformasi Agama-Agama. Salatiga: Satya Wacana University Press.

[23] Maarif, Ahmad Syafii. 2010. Politik Identitas Dan Masa Depan Pluralisme Kita. Jakarta: Pusat Studi Agama dan Demokrasi. 